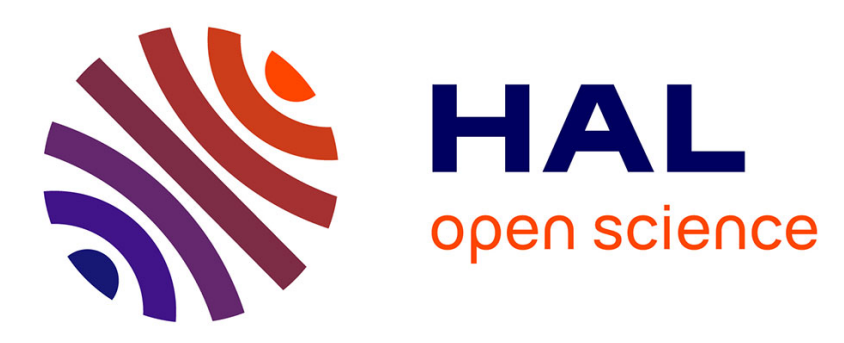

\title{
Elaboration and characterizations of platinum nanoparticles supported on cellulose-based carbon aerogel
}

Joanna Rooke, Claudia Hildenbrand, Sandrine Berthon-Fabry, Romain Sescousse, Tatiana Budtova, Marian Chatenet, Frédéric Maillard

\section{To cite this version:}

Joanna Rooke, Claudia Hildenbrand, Sandrine Berthon-Fabry, Romain Sescousse, Tatiana Budtova, et al.. Elaboration and characterizations of platinum nanoparticles supported on cellulose-based carbon aerogel. International Carbon Conference 2009, Jun 2009, Biarritz, France. 6 p. hal-00490263

HAL Id: hal-00490263

https://hal-mines-paristech.archives-ouvertes.fr/hal-00490263

Submitted on 16 Jun 2010

HAL is a multi-disciplinary open access archive for the deposit and dissemination of scientific research documents, whether they are published or not. The documents may come from teaching and research institutions in France or abroad, or from public or private research centers.
L'archive ouverte pluridisciplinaire HAL, est destinée au dépôt et à la diffusion de documents scientifiques de niveau recherche, publiés ou non, émanant des établissements d'enseignement et de recherche français ou étrangers, des laboratoires publics ou privés. 


\title{
Elaboration and characterizations of platinum nanoparticles supported on cellulose-based carbon aerogel
}

\author{
Joanna Rooke $^{1^{*}}$, Claudia Hildenbrand ${ }^{2}$, Sandrine Berthon-Fabry ${ }^{2}$, Romain Sescousse ${ }^{3}$, Tatiana Budtova ${ }^{3}$, Marian \\ Chatenet $^{1}$, Frédéric Maillard ${ }^{1}$ \\ 1 LEPMI, UMR 5631 CNRS/Grenoble-INP/UJF, BP75, F-38402 St Martin d'Hères Cedex (France) \\ 2 MINES Paristech, Centre Energétique et Procédés - CEP, BP 207, F-06904 Sophia-Antipolis Cedex (France) \\ ${ }^{3}$ MINES Paristech, Centre de Mise en Forme des Matériaux - $\mathrm{CEMEF}^{\dagger}$, UMR CNRS/Ecole des Mines de Paris 7635, BP \\ 207, 06904 Sophia-Antipolis Cedex, France \\ *Corresponding author. E-mail : jc_rooke@hotmail.com
}

\begin{abstract}
This work investigates the deposition of Pt nanoparticles onto carbon aerogels (CA), derived from microcrystalline cellulose. Nanoparticles are synthesised via impregnating the CA with $\mathrm{H}_{2} \mathrm{PtCl}_{6}$ followed by reduction either under $\mathrm{H}_{2}$ at 300 ${ }^{\circ} \mathrm{C}$ or in a basic $\mathrm{NaBH}_{4}$ solution. $\mathrm{H}_{2}$ reduction yields uniform Pt nanoparticles (average diameter $<2 \mathrm{~nm}$ ) dispersed over the CA surface as revealed by Transmission electron microscopy (TEM). Larger agglomerates can be seen in TEM images of $\mathrm{NaBH}_{4}$ reduced samples, which is confirmed by powder X-ray diffraction (XRD). A rotating disk electrode was employed to analyse the electrochemical properties of the Pt nanoparticles. The active area of the platinum nanoparticles was evaluated using hydrogen adsorption/desorption cyclic voltammetry and $\mathrm{CO}$ stripping measurements. The oxygen reduction reaction was also studied to (i) obtain the kinetic parameters of oxygen reduction for the Pt/CA materials and (ii) compare them with commercial Pt/Carbon Black.
\end{abstract}

\section{Introduction}

A vital problem facing mankind today is the scarcity of fossil fuels, essential in many day to day activities. One potential alternative energy source is hydrogen which can be used to power a proton exchange membrane fuel cell (PEMFC). Such fuel cells are advantageous owing to high power density, low operating temperatures and zero-emissions as simply water and heat are produced [1,2]. Research is ongoing to modify and optimise such devices in order to reduce the amount of costly platinum electrocatalyst required and to find cleaner supports for this platinum [3-6 and refs therein].

Currently carbon-blacks (CB) are used in commercial high-tech electrocatalysts owing to their high surface area to volume ratios. CBs however are not eco-friendly, they originate from the incomplete combustion of heavy petroleum feedstocks. Conversely cellulose, a polysaccharide, is an abundant, readily available green material. Through the dissolution, regeneration, drying and pyrolysis of cellulose one can obtain lightweight and highly porous carbon matrices of large specific surface areas [7-8 and refs therein]. Furthermore CB nanoparticles are aggregates whereas CAs are prepared as monoliths with internal porosities of over $90 \%$ of the total volume $[4,5,8]$. By tailoring the pore size the resulting material should allow enhanced diffusion of reactant gases within the electrode and a better penetration of the proton conducting ionomer [9-10].

Carbon aerogels were first developed by Pekala in 1989 [11]. This discovery has sparked interest amongst electrochemists and consequently fundamental research is being conducted regards the viability of these materials as catalytic supports. Both cellulose acetate based [12] and resorcinol-formaldehyde based carbon aerogels [4] have previously been studied as suitable alternatives to $\mathrm{CB}$ with electrochemical activities comparable to commercial benchmark catalysts.

This work principally focuses on carbon aerogels derived from microcrystalline cellulose. Ultra-light and highly porous cellulose can be obtained from cellulose solutions via supercritical drying [13]. Pyrolysis then results in a carbon framework yielding a form of carbon aerogel. This abstract summarises the optimisation of platinum nanoparticle impregnation within such CA materials. The active area of the platinum nanoparticles was

\footnotetext{
${ }^{\dagger}$ Member of the European Polysaccharide Network of Excellence (EPNOE), www.epnoe.eu
} 
evaluated using hydrogen adsorption/desorption cyclic voltammetry and $\mathrm{CO}$ stripping measurements. The oxygen reduction reaction was also studied.

\section{Experimental Methods}

\section{$2.1 \quad$ Synthesis of Carbon Aerogel:}

The procedure used was one adapted from the literature [13]. Avicel $\mathrm{Ph}-101$ microcrystalline cellulose was mixed with water and maintained at $5{ }^{\circ} \mathrm{C}$ allowing cellulose to swell. Concurrently a $12 \% \mathrm{NaOH}$ solution was pre-cooled to $-6{ }^{\circ} \mathrm{C}$. The two mixtures were added together in such a proportion that the final product contains $5 \%$ of cellulose dissolved in $8 \% \mathrm{NaOH} /$ water. The mixture was kept at $-6^{\circ} \mathrm{C}$ whilst being mechanically stirred at $1,000 \mathrm{rpm}$ for 2 hours. The obtained solution was subsequently poured into a mould and heated at $50{ }^{\circ} \mathrm{C}$ for 20 hours to form a gel [13]. Cellulose was then regenerated in a non-solvent bath (acetic acid, $0.1 \mathrm{M}$ ) and washed in water to remove any traces of $\mathrm{NaOH}$ and acid. Swollen-in-water pure cellulose "blocks" were obtained. Drying was carried out under supercritical conditions. As water is not miscible with $\mathrm{CO}_{2}$, it was replaced by acetone by washing regenerated samples in several acetone baths and swollen-in-acetone carbon aerogel precursors were obtained. These were placed in a $1 \mathrm{~L}$ autoclave filled with acetone to prevent evaporation prior to $\mathrm{CO}_{2}$ supercritical drying. Wet gels were first washed under supercritical flow of carbon dioxide $\left(\mathrm{CO}_{2}\right)$ at 85 bars, $37^{\circ} \mathrm{C}$ and $5 \mathrm{~kg}_{\mathrm{CO} 2} / \mathrm{h}$. When the whole interstitial liquid phase was recovered, $\mathrm{CO}_{2}$ was vented out slowly (5 $\mathrm{bar} / \mathrm{min})$ and isothermally $\left(37^{\circ} \mathrm{C}\right)$ to prevent any condensation phenomena. The organic aerogel obtained was then pyrolised under an inert nitrogen atmosphere at $1050^{\circ} \mathrm{C}$ to obtain a carbon aerogel.

\section{$2.2 \quad$ Pt Nanoparticle Deposition}

Electrocatalysts were prepared by impregnating a predetermined amount of hexachloroplatinic acid, $\mathrm{H}_{2} \mathrm{PtCl}_{6} \cdot 6 \mathrm{H}_{2} \mathrm{O}$ (Alfa Aesar, 99\%) onto the pre-ground CA support. The suspended CA was left in the acidic solution under constant agitation for $72-96 \mathrm{hrs}$ at ambient temperature. The mixture was then filtered and dried at $110^{\circ} \mathrm{C}$ in air overnight before undergoing reduction. The reduction was carried out in one of two ways, either under flowing hydrogen at $300{ }^{\circ} \mathrm{C}$ for 2 hours and subsequently cooled under argon (Method A) or by using $\mathrm{NaBH}_{4}$. In the latter case the pre-dried catalyst was suspended in a solution of $\mathrm{NaOH}(50 \mathrm{~mL}, 0.1 \mathrm{M}, \mathrm{pH}>12)$ into which a twenty fold excess of $\mathrm{NaBH}_{4}$ in a basic solution $(50 \mathrm{~mL}, 0.1 \mathrm{M}, \mathrm{NaOH})$ was added and left to react for 60 minutes. Afterwards the mixture was filtered and washed with hot water to remove any cationic platinum and boron containing species prior to drying overnight at $110{ }^{\circ} \mathrm{C}$ (Method B). Finally in one case the impregnation solution was reacted directly with the $\mathrm{NaBH}_{4}$ reductant in-situ without filtration. Table 1 outlines the reaction conditions of each sample reported herein.

Table 1. Fabrication conditions of platinum impregnation

\begin{tabular}{ccccccc}
\hline Sample & $\begin{array}{c}\text { Mass CA } \\
(\mathrm{mg})\end{array}$ & $\begin{array}{c}\text { wt \% Pt } \\
\text { targeted }\end{array}$ & $\begin{array}{c}\mathrm{Pt} \text { conc / } \\
\left(\mathrm{mol} \mathrm{dm}^{-3}\right)\end{array}$ & $\begin{array}{c}\text { Volume } \\
\text { impregnation } \\
\text { solution } \\
(\mathrm{mL})\end{array}$ & $\begin{array}{c}\text { Impregnation } \\
\text { time } \\
(\mathrm{hrs})\end{array}$ & $\begin{array}{c}\text { Reduction } \\
\text { method }\end{array}$ \\
\hline I & 200 & 23 & 0.012 & 25 & 96 & $\mathrm{H}_{2}, 300^{\circ} \mathrm{C}$ \\
\hline II & 200 & 23 & 0.012 & 25 & 96 & $\begin{array}{l}\mathrm{NaBH}_{4}, \text { after } \\
\text { filtration }\end{array}$ \\
\hline III & 200 & 23 & 0.012 & 25 & 72 & $\begin{array}{l}\mathrm{NaBH}_{4} \text {, before } \\
\text { filtration }\end{array}$ \\
\hline
\end{tabular}

\subsection{Analytical Techniques}

Powder X-ray diffraction (XRD) was carried out on a PanAlytical X'Pert Pro MPD. High Resolution Transmission electron microscopy (HR-TEM) was performed on a Jeol 2010 HRTEM. The platinum 
concentration remaining in the impregnation solution was determined via inductively coupled plasma atomic emission spectroscopy (ICP-AES) measurements on a Perkin Elmer - Optima 3000XL.

\subsection{Electrochemical characterisation}

The electrochemical activity was studied in a three electrode cell using a rotating disk electrode, whereby an active layer was prepared from a water based ink which contained the electrocatalyst and $50 \mathrm{wt} \%$ Nafion (5 wt $\%$ in solvent water-ethanol mixture, Aldrich). After 15 minutes sonication, a $10 \mu \mathrm{L}$ ink drop was deposited onto a $0.196 \mathrm{~cm}^{2}$ vitreous carbon surface, such that the targeted active layer contained $91 \mu \mathrm{g}$ of dry material. The solvent was evaporated at $80^{\circ} \mathrm{C}$ prior to Nafion recasting $\left(120^{\circ} \mathrm{C}, 20 \mathrm{mins}\right)$. The analysis was carried out with a PC-controlled numeric potentiostat (AUTOLAB PGSTAT 20) with a saturated calomel electrode (SCE) as a reference $(+0.245 \mathrm{~V}$ vs NHE). The electroactive platinum surface area was calculated from hydrogen adsorption desorption coulometry and from CO-stripping experiments. Conversely the activity of the catalysts was evaluated by voltammetry experiments exploiting the oxygen reduction reaction. Briefly, the electrochemical analyses have been conducted in $1 \mathrm{M} \mathrm{H}_{2} \mathrm{SO}_{4}$ at room temperature $\left(20^{\circ} \mathrm{C}\right)$ under the appropriate atmosphere ( $\mathrm{Ar}$ or $\mathrm{O}_{2}$ ). Details regarding these electrochemical procedures can be found in references [7, 8].

\section{Results and Discussion}

When reduction is carried out under flowing $\mathrm{H}_{2}$ TEM has shown that the platinum nanoparticles are generally highly dispersed and uniform in size, with diameters typically in the region of 1-2 $\mathrm{nm}$. Additionally hardly any agglomerates can be detected. Conversely using $\mathrm{NaBH}_{4}$ there is a tendency to form agglomerates. This is especially the case when the reduction is carried out in-situ prior to filtration. This forces more Pt onto the support, although not all of the Pt is chemisorbed onto the surface of the CA (Figure 1).
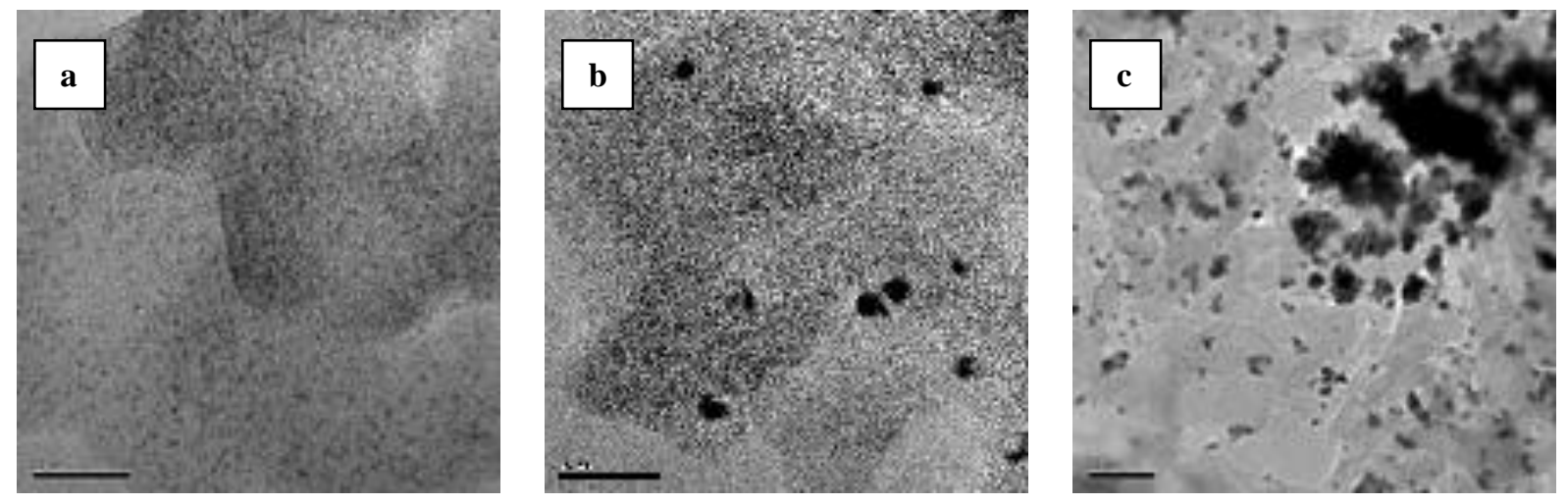

Figure 1: TEM images showing Pt adsorption on CA after reduction with (a) $\mathrm{H}_{2}$, scale bar $20 \mathrm{~nm}$ (b) $\mathrm{NaBH}_{4}$ after filtration, scale bar $50 \mathrm{~nm}$ and (c) $\mathrm{NaBH}_{4}$ before filtration, scale bar $50 \mathrm{~nm}$.

Analysis by powder XRD shows that the 1-2 nm sized platinum nanoparticles seen in the TEM images do not give a response in the powder XRD patterns (Figure 2). Their small size means that they are in fact below the limit of detection considering one assumption of the technique is that of an infinite periodicity of the scattering lattice. In contrast when reduction is carried out in an alkaline solution of $\mathrm{NaBH}_{4}$ (Figure 1c) particle size is no longer uniform. Big agglomerates form which can be in scale of $50-150 \mathrm{~nm}$. It is these regions that give rise to a crystalline Pt profile in the XRD data.

ICP-AES measurements were undertaken on the impregnation solutions after the samples were recuperated to give an idea as to the concentration of platinum deposited on the support (Table 2). The results confirm that reducing the $\mathrm{Pt}^{2+}$ species in-situ leads to a far greater amount of $\mathrm{Pt}^{0}$ driven onto the support during the filtration step. What is interesting is the difference between impregnation levels in samples I and II, where the reduction is carried out after the excess unimpregnated $\mathrm{Pt}^{2+}$ has been removed by filtration. This can be attributed to various 
differences in the impregnation process. As the temperature was not controlled fluctuations in ambient temperature may result in different levels of impregnation.

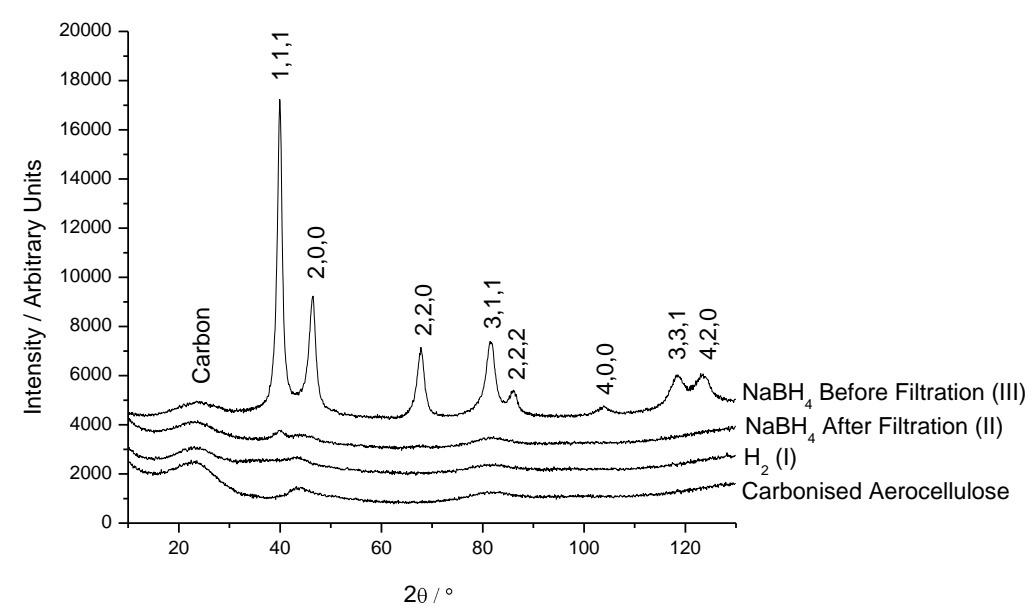

Figure 2 : XRD patterns showing Pt adsorption on CA after reduction with $\mathrm{H}_{2}$ and with $\mathrm{NaBH}_{4}$ either before or after filtration. The pattern generated from the CA support is also shown.

Table 2. ICP-AES measurements revealing the mass of Pt impregnated deduced from the concentration of solution after impregnation.

\begin{tabular}{cccc}
\hline Sample & $\begin{array}{c}\text { Pt in solution } \\
(\mathrm{mg})\end{array}$ & $\begin{array}{c}\text { Pt impregnated } \\
(\mathrm{mg})\end{array}$ & $\begin{array}{c}\text { Pt } \\
(\mathrm{wt} \%)\end{array}$ \\
\hline I & 56.3 & 4.29 & 2.1 \\
\hline II & 52.0 & 8.56 & 4.1 \\
\hline III & 8.18 & 52.4 & 20.8 \\
\hline
\end{tabular}

Presented in Figure 3 are a few electrochemical characterisations of sample I as this sample had a uniform distribution of homogeneous nanoparticles. The voltamperogram from the adsorption-desorption of hydrogen reveals the presence of active Pt owing to the characteristic peaks between 0.5 and $0.2 \mathrm{~V}$ vs NHE. It appears that the oxygen reduction reaction (ORR) cleans the surface of the platinum, thus increasing the active surface area. This is shown in figure 3a during further analysis of the adsorption and desorption of hydrogen (ADH) by cyclic voltammetry after ORR where the characteristic peaks have increased in size. Subsequent CO stripping analyses on the same ink have proved to be superimposable and thus reproducible results can be obtained.

Analysis of the other samples (not shown here) has revealed greater activities owing to larger particles and higher loadings of $\mathrm{Pt}$, with the sample reduce by $\mathrm{NaBH}_{4}$ prior to filtration (in-situ) having the greatest ORR activity. After further, more thorough, analyses these results will be reported shortly. 

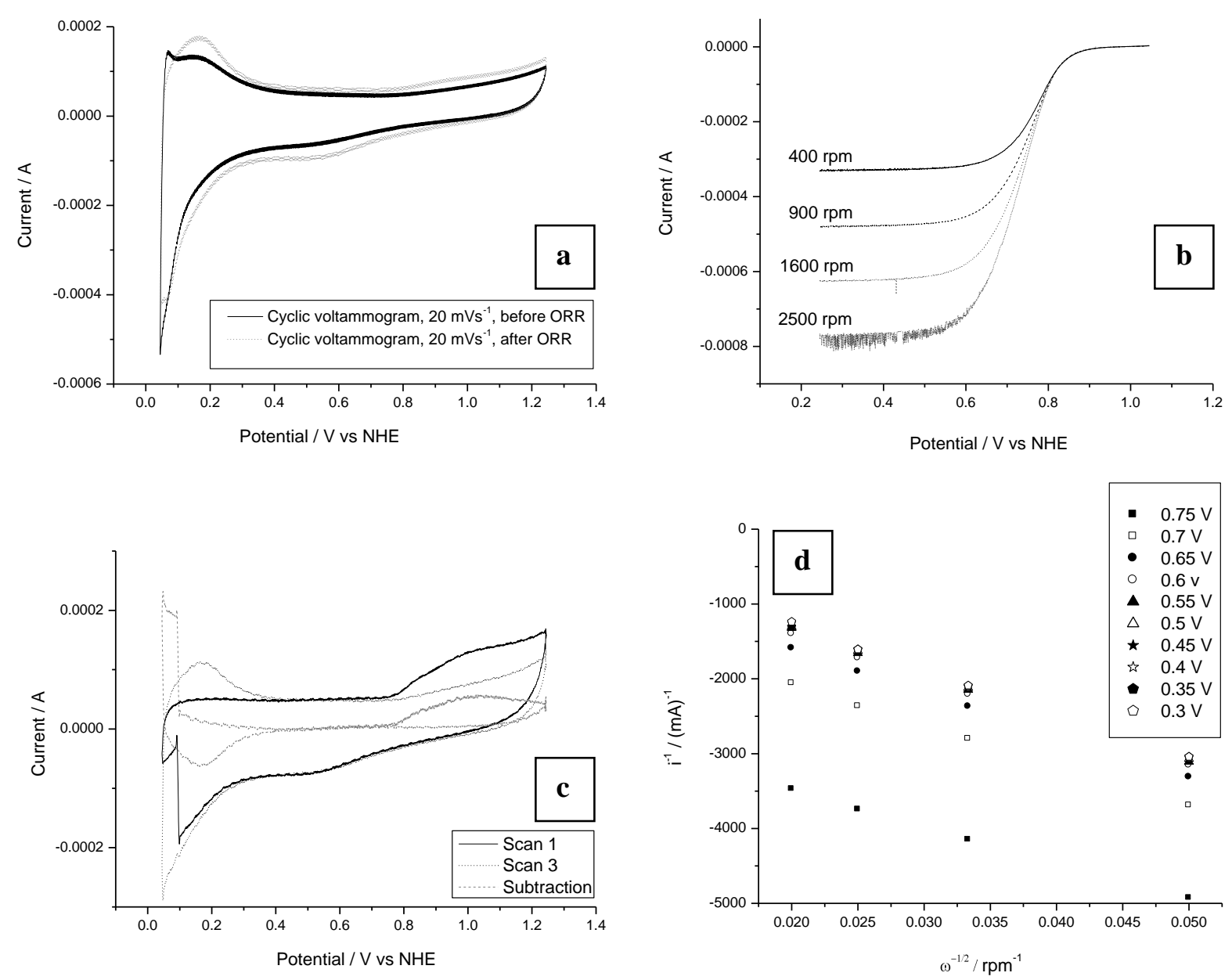

Figure 3 : Voltamperograms for (a) adsorption-desorption of hydrogen, (b) oxygen reduction reaction, (c) CO stripping before the oxygen reduction reaction and (d) Koutecky-Levich graphs for sample I, Pt/CA reduced under $\mathrm{H}_{2}$ at $300{ }^{\circ} \mathrm{C}$. Results obtained using a rotating disk electrode.

\section{Conclusion}

Cellulose aerogels are "green" products, with architectures controlled by the synthesis parameters which in turn can yield materials with not only large specific surface areas (increasing the distribution of nanoparticles over the surface) but also large porous volumes (minimising problems of diffusion of the reactant gases). Conversely commercial carbon black supports are petroleum derivatives comprised of a random arrangement of aggregate particles held together by Van der Waals forces. Their porosity cannot be tailored unlike aerogels and is defined as the interparticulate voids, which results in a fixed surface area much smaller than the pore network within carbon aerogel monoliths. These compounds display a macroporosity which is far more advantageous as the increase in the void space facilitates the adsorption of hydrogen onto the chemisorbed platinum species.

Electrochemical analyses of these catalysts is ongoing but results thus far have revealed how the ORR reaction cleans the surface of the Pt/CA catalysts achieving higher active Pt surface areas. These preliminary results coupled with chemicophysical characterisations of the materials show that homogeneously sized Pt nanoparticles can be uniformly deposited onto carbon aerogels derived from microcrystalline cellulose using standard techniques. However careful attention must be paid to the conditions of the impregnation in order to optimise the electrocatalysts obtained. The most dramatic remark is the difference between reducing agent. $\mathrm{NaBH}_{4}$ has a tendency to form agglomerates of $\mathrm{Pt}$ as opposed to the uniform sized and well-distributed $\mathrm{Pt}$ nanoparticles produced via $\mathrm{H}_{2}$ reduction. This is a common problem and thus $\mathrm{H}_{2}$ reduction is favoured over $\mathrm{NaBH}_{4}$. As the platinum surface area is increased when small nanoparticles are formed in preference to agglomerates the active surface area and thus the efficiency of the catalyst could theoretically be improved. Furthermore a key objective Topic 04 
in PEMFC research is minimising the amount of expensive Pt by maximising the active surface area. Work must now focus on increasing the amount of Pt chemisorbed onto the surface of the CA through modifying parameters such as $\mathrm{pH}$ of impregnation solution, temperature of impregnation, time of impregnation and so forth.

\section{References}

[1] W. Vielstich, A. Lamm, H. A. Gasteiger, Handbook of Fuel Cells Vol. 1-4., Wiley, 2003.

[2] H. A. Gasteiger, W. Vielstich, H. Yokokawa, Handbook of Fuel Cells Vol 5, John Wiley \& Sons Ltd, 2009.

[3] J. Marie, S. Berthon-Fabry, P. Achard, M. Chatenet, A. Pradourat, E. Chainet, J. Non-Cryst. Solids, 350 (2004) 88-96.

[4] J. Marie, S. Berthon-Fabry, M. Chatenet, E. Chainet, R. Pirard, N. Cornet, P. Achard, J. Appl. Electrochem., 37 (2007) 147-153.

[5] J. F. Marie, S. Berthon-Fabry, P. Achard, M. Chatenet, E. Chainet, R. Pirard, N. Cornet, ECS Trans., 1 (2006) 509-519.

[6] J. Marie, R. Chenitz, M. Chatenet, S. Berthon-Fabry, N. Cornet, P. Achard, J. Power Sources, In Press, Accepted Manuscript (2009)

[7] E. Guilminot, F. Fischer, M. Chatenet, A. Rigacci, S. Berthon-Fabry, P. Achard, E. Chainet, J. Power Sources, 166 (2007) 104-111.

[8] E. Guilminot, R. Gavillon, M. Chatenet, S. Berthon-Fabry, A. Rigacci, T. Budtova, J. Power Sources, 185 (2008) 717-726.

[9] N. Job, J. Marie, S. Lambert, S. Berthon-Fabry, P. Achard, Energ. Convers. Manage., 49 (2008) 2461-2470.

[10] N. S. Lambert, N. Job, L. D’Souza, M. F. Ribeiro Pereira, R. Pirard, B. Heinrichs, J. L. Figueiredo, J. P. Pirard, J. R. Regalbuto, J. Catal., 261 (2009) 23-33.

[11] R.W. Pekala, J. Mater. Sci., 24 (1989) 3221-3227.

[12] F. Fischer, A. Rigacci, R. Pirard, S. Berthon-Fabry, P. Achard, Polymer, 47, (2006) 7636-7645.

[13] R. Gavillon, T. Budtova, Biomacromolecules, 9 (2008) 269-277. 